\title{
Water Requirement and its Trend for Rice and Wheat Crops in Haryana State, India
}

\author{
Shaloo*, Himani Bisht, A. Sarangi, V. K. Prajapati, A. K. Mishra and Man Singh \\ ICAR- Indian Agricultural Research Institute, New Delhi, India \\ *Corresponding author
}

Key w o r d s
Penman-Monteith,
Reference crop
evapotranspiration,
Crop water
requirement, Crop
coefficient

\section{A B S T R A C T}

Estimation of crop water requirement is essential for agricultural planning and irrigation scheduling. The aim of this study was to compute the water requirement of wheat and rice crops for all districts of Haryana. Climatic data on maximum and minimum temperature, rainfall, relative humidity, wind speed and solar radiation were used to estimate the reference evapotranspiration $\left(\mathrm{ET}_{\mathrm{o}}\right)$ at different gridded locations by using Penman Monteith method in MATLAB software. Further, the actual evapotranspiration for rice crop grown in the region was estimated by multiplying the $\mathrm{ET}_{\mathrm{o}}$ with crop coefficient $(\mathrm{Kc})$ values. Subsequently, the effective rainfall and the irrigation water requirement for wheat and rice crops at gridded points pertaining to different districts of Haryana were estimated. Thereafter the trend analysis was performed by using non parametric Mann Kendall test by using MATLAB software. Results indicated that water requirement $\left(\mathrm{ET}_{\mathrm{C}}\right)$ of wheat was increasing significantly for eleven districts viz. Ambala, Bhiwani, Fatehabad, Hisar, Jind, Kurukshetra, Mahendargarh, Panchkula, Panipat, Sonipat and Yamunagar while in case of rice crop it was increasing significantly only for eight districts viz. Bhiwani, Fatehabad, Hisar, Sirsa, Jind, Kurukshetra, Panipat and Sonipat. This work can help in water management practices for better irrigation management.

\section{Introduction}

In India, decreasing water availability is one of the major problems over last few decades that could severely restrict agricultural development. Knowledge of the exact amount of water required by different crops in a given set of climatic conditions of a region is important for planning of irrigation schemes that requires accurate estimation of crop water requirement. Remote Sensing (RS) and Geographical Information System (GIS) techniques have emerged as powerful tools for crop water management.Crop water requirement refers to the amount of water needed to compensate for the evapotranspiration loss from the field crop (Allen et al., 1998). Supit et al., (2010) analyzed trends for water demand, consumption, and deficit in field crops throughout Europe. Pakhale et al., (2010) estimated the crop water requirement for wheat crop in Karnal district of Haryana and observed that wheat water requirement was higher in the vegetative and mid-season stage and shows decreasing trend towards the 
maturity stage. In the study area it was found that irrigation water requirement highly correlated with crop water requirement due to absence of monsoon in rabi season (November to March).Singh et al., (2010) reported that improper irrigation water management would make the rice-wheat cropping system of Haryana unsustainable with dwindling quantity and deteriorating quality of the ground water resources in the region. Singh et al., (2013) estimated crop evapotranspiration for Cotton crop in Sirsa district of Haryana and reported that the spatial distribution of seasonal ETc. varied between 317 to $534 \mathrm{~mm}$ for growing season of cotton depending upon sowing date and other condition. Vibhuteet al., (2016) developed Crop Water Demand Based Water Delivery Schedule for a canal command for the Jhajjar distributary of western Yamuna canal command in Haryana, India and observed that the gross irrigation water requirement of wheat was $363.4 \mathrm{~mm}$ and that of rice was $1386 \mathrm{~mm}$ with effective rainfall depths of 55.8 and $461.8 \mathrm{~mm}$ during the wheat (rabi) and rice (kharif) growing seasons, respectively. Khandelwal and Dhiman (2017) estimated Net Irrigation

Requirement of different crops of Limbasi Canal command area, Gujarat and reported that estimated average NIR of 19 years for kharif crops paddy \&vegetables was 229.8 \& $92.9 \mathrm{~mm}$ and for rabi crops sorghum, tobacco, wheat \& vegetables was $355.5,391,427.2 \&$ $407.1 \mathrm{~mm}$ and hot weather crops paddy, pearl millet \& vegetables was $863.9,600.6 \& 754.7$ $\mathrm{mm}$ respectively. The Penman-Monteith method, which is recommended by FAO, has been widely used to calculate $\mathrm{ET}_{\mathrm{o}}$ in recent years (Cai et al., 2007; Yin et al., 2008).Yadav et al., (2019) calculated crop water requirement using Modified Penman Equation and Duty Delta method for present cropping pattern and reported that, approximately $50 \%$ of water could be saved using modified Penmen method compared to crop water requirement calculated using Duty Delta method. Tezera et al., (2019) reported that the seasonal ETc was found to be $52.2 \mathrm{~mm}, 97.1 \mathrm{~mm}, 191.5 \mathrm{~mm}$ and $73.2 \mathrm{~mm}$ of water calculated for initial, crop development, mid-season, and late-season stages, respectively. The measured crop coefficient (Kc) values were $0.54,1.15$ and 0.67 for the initial, mid and late stages, respectively. Some of the Kc values found slightly different from the average of FAO estimation.

Data on evapotranspiration is a fundamental requirement for develop in gannual irrigation plans and estimating the amount of water used in agricultural environments (Kuo et al., 2011). Because most of the available water resources are used in agriculture, an accurate estimation of crop evapotranspiration helps in the efficient management of the limited water resources by irrigation associations(Cai et al., 2007; Lovelli et al., 2008).With the above background the aim of this study was to assess crop water requirement for wheat and rice crops in Haryana.

\section{Materials and Methods}

\section{Study area}

State is situated in the north western part of India, between $27^{\circ} 39^{\prime}$ to $30^{\circ} 55.5^{\prime} \mathrm{N}$ latitude and $74^{\circ} 27.8^{\prime}$ to $77^{\circ} 36.5^{\prime} \mathrm{E}$ longitude. Total area of the state is $44212 \mathrm{~km}^{2}$ which constitutes about $1.35 \%$ of total geographical area of the country. The height above mean sea level is generally 200 to $300 \mathrm{~m}$ in about $90 \%$ of the area, which rises to $450 \mathrm{~m}$ in southern part with Aravalli hills and more than $1000 \mathrm{~m}$ in north eastern parts with Siwalik Hills. Temperature regime over the entire state area is hypothermic as the mean annual, mean summer and mean winter air temperatures are $26.3^{\circ} \mathrm{C}, 33.3^{\circ} \mathrm{C}$ and $16.2^{\circ} \mathrm{C}$, respectively. 


\section{Data acquisition}

Gridded climatic data $\left(1^{\circ} \times 1^{\circ}\right)$ on maximum and minimum temperature, rainfall, relative humidity, wind speed and solar radiation downloaded for a period from $1^{\text {st }}$ January 1985 to $31^{\text {st }}$ December 2015 from secondary sources of NASA Climatology Resources for Agro-climatology. Available climatic parameters were further used to estimate the reference evapotranspiration $\left(\mathrm{ET}_{\mathrm{o}}\right)$ at different gridded locations by using Penman Monteith method in MATLAB software.

Further, the actual evapotranspiration for wheat and rice crop grown in the region was estimated by multiplying the $\mathrm{ET}_{0}$ with crop coefficient $(\mathrm{Kc})$ values. Thereafter the trend analysis was performed by using non parametric Mann Kendall test by using MATLAB software. The Penman-Monteith equation used for estimation of reference evapotranspiration $\left(\mathrm{ET}_{\mathrm{o}}\right)$ is given by:

$E T_{0}=\frac{0.408 \Delta\left(R_{n}-G\right)+\gamma \frac{900}{T+273} U_{2}\left(e_{s}-e_{a}\right)}{\Delta+\gamma\left(1+0.34 U_{2}\right)}$

Where

$\mathrm{ET}_{\mathrm{o}}=$ reference evapotranspiration $\left[\mathrm{mm} \mathrm{day}^{-1}\right]$ $\mathrm{R}_{\mathrm{n}}=$ net radiation at the crop surface $\left[\mathrm{MJ} \mathrm{m}^{-2}\right.$ day $^{-1}$ ]

$\mathrm{G}=$ soil heat flux density $\left[\mathrm{MJ} \mathrm{m}^{-2}\right.$ day $\left.^{-1}\right]$

$\mathrm{T}=$ mean daily air temperature at $2 \mathrm{~m}$ height $\left[{ }^{\circ} \mathrm{C}\right]$

$\mathrm{u}_{2}=$ wind speed at $2 \mathrm{~m}$ height $\left[\mathrm{m} \mathrm{s}^{-1}\right.$ ]

$\mathrm{e}_{\mathrm{s}}=$ saturation vapour pressure $\left[\mathrm{kP}_{\mathrm{a}}\right]$

$\mathrm{e}_{\mathrm{a}}=$ actual vapour pressure $\left[\mathrm{kP}_{\mathrm{a}}\right]$

$\left[\mathrm{e}_{\mathrm{s}}-\mathrm{e}_{\mathrm{a}}\right]=$ saturation vapour pressure deficit $\left[\mathrm{kP}_{\mathrm{a}}\right]$

$\Delta=$ slope vapour pressure curve $\left[\mathrm{kP}_{\mathrm{a}}{ }^{\circ} \mathrm{C}^{-1}\right]$

$\gamma=$ psychrometric constant $\left[\mathrm{kP}_{\mathrm{a}}{ }^{\circ} \mathrm{C}^{-1}\right]$

Crop water requirement is estimated from the product of $\mathrm{ET}_{\mathrm{o}}$ multiplied by the crop coefficient.Crop coefficient values of wheat and rice are shown in Fig.1.

$\mathrm{CWR}=\mathrm{Kc} * \mathrm{ET}_{\mathrm{o}}$

\section{Results and Discussion}

Crop water requirement of rice and wheat crops were estimated and spatial variability maps were developed for the year 1990, 1995, 2000, 2005,2010 and 2015 using the GIS software ArcMap10.1. Trend analysis was performed by using non parametric Mann Kendall test by using MATLAB software.

\section{Crop water requirement of wheat and rice}

The result indicated that water requirement $\left(E T_{C}\right)$ of wheat was increasing significantly for eleven districts viz. Ambala( Sen's slope 2.77), Bhiwani (Sen's slope 3.08), Fatehabad (Sen's slope 3.26), Hisar(Sen's slope 3.24), Jind(Sen's slope 2.51), Kurukshetra(Sen's slope 2.50), Mahendargarh (Sen's slope 2.16) , Panchkula (Sen's slope 3.09), Panipat(Sen's slope 2.14), Sonipat(Sen's slope 2.51)and Yamunagar (Sen's slope 3.35) but for other remaining districts no significant trend was observed (Table 1).The crop water requirement for Ambala, Fatehabd, Panchkula and Yamunanagar was found less than 500 $\mathrm{mm}$ and only for Faridabad it was observed higher which was found between the range $550-600 \mathrm{~mm}$ and for other remaining five districts it was noticed between the ranges $500-550 \mathrm{~mm}$ in the year 1990. During the year 2000 Yamunanagr was the only district which was observed with the crop water requirement less than $500 \mathrm{~mm}$. Mahendargarh and Faridabad were found between the range 550-600 $\mathrm{mm}$ and the other remaining eight districts were observed between the range 500-550 mm. 
Table.1 Trend test statistics and interpretation of crop water requirement of wheat

\begin{tabular}{|l|l|l|l|l|l|}
\hline Mann-Kendall test & \multicolumn{3}{l|}{ Significance } \\
\hline Districts Name & Kendall's tau & p-value (Two-tailed) & Sen's slope & $\begin{array}{l}\text { Test } \\
\text { interpretation }\end{array}$ & \\
\hline Ambala & 0.25 & 0.04 & 2.77 & Trend increasing & S \\
\hline Bhiwani & 0.24 & 0.05 & 3.08 & Trend increasing & S \\
\hline Fatehabad & 0.33 & 0.00 & 3.26 & Trend increasing & S \\
\hline Hisar & 0.33 & 0.00 & 3.24 & Trend increasing & S \\
\hline Kaithal & 0.24 & 0.06 & 2.18 & Trend increasing & NS \\
\hline Karnal & 0.24 & 0.06 & 2.18 & Trend increasing & NS \\
\hline Rohtak & 0.22 & 0.08 & 1.89 & Trend increasing & NS \\
\hline Palwal & 0.08 & 0.54 & 0.68 & Trend increasing & NS \\
\hline Sirsa & 0.27 & 0.03 & 3.33 & Trend increasing & NS \\
\hline Faridabad & 0.09 & 0.49 & 0.73 & Trend increasing & NS \\
\hline Gurgaon & 0.23 & 0.07 & 1.94 & Trend increasing & NS \\
\hline Jhajjar & 0.20 & 0.16 & 1.65 & Trend increasing & NS \\
\hline Jind & 0.27 & 0.03 & 2.51 & Trend increasing & S \\
\hline Kurukshetra & 0.27 & 0.03 & 2.50 & Trend increasing & S \\
\hline Mahendergarh & 0.26 & 0.04 & 2.16 & Trend increasing & S \\
\hline Panchkula & 0.28 & 0.03 & 3.09 & Trend increasing & S \\
\hline Panipat & 0.25 & 0.06 & 2.14 & Trend increasing & S \\
\hline Rewari & 0.14 & 0.34 & 1.05 & Trend increasing & NS \\
\hline Sonipat & 0.27 & 0.03 & 2.51 & Trend increasing & S \\
\hline Yamunanagar & 0.33 & 0.01 & 3.35 & Trend increasing & S \\
\hline "S-Signifing & & &
\end{tabular}

*S-significant NS-not significant

Table.2 Trend test statistics and interpretation of crop water requirement of rice

\begin{tabular}{|l|l|l|l|l|l|}
\hline \multicolumn{7}{|c|}{ Mann-Kendal test } \\
\hline Districts Name & Kendall's tau & p-value (Two-tailed) & Sen's slope & Test interpretation & Significance \\
\hline Ambala & 0.11 & 0.37 & 2.34 & Trend increasing & NS \\
\hline Bhiwani & 0.32 & 0.01 & 7.64 & Trend increasing & S \\
\hline Fatehabad & 0.34 & 0.008 & 7.05 & Trend increasing & S \\
\hline Hisar & 0.34 & 0.008 & 7.04 & Trend increasing & S \\
\hline Kaithal & 0.23 & 0.06 & 4.81 & Trend increasing & NS \\
\hline Karnal & 0.23 & 0.06 & 4.81 & Trend increasing & NS \\
\hline Rohtak & 0.21 & 0.09 & 3.84 & Trend increasing & NS \\
\hline Palwal & 0.14 & 0.25 & 2.91 & Trend increasing & NS \\
\hline Sirsa & 0.38 & 0.003 & 10.96 & Trend increasing & S \\
\hline Faridabad & 0.17 & 0.19 & 3.70 & Trend increasing & NS \\
\hline Gurgaon & 0.24 & 0.06 & 4.55 & Trend increasing & NS \\
\hline Jhajjar & 0.24 & 0.06 & 4.55 & Trend increasing & NS \\
\hline Jind & 0.26 & 0.04 & 5.43 & Trend increasing & S \\
\hline Kurukshetra & 0.25 & 0.05 & 4.63 & Trend increasing & S \\
\hline Mahendergarh & 0.24 & 0.06 & 4.53 & Trend increasing & NS \\
\hline Panchkula & 0.12 & 0.34 & 2.94 & Trend increasing & NS \\
\hline Panipat & 0.26 & 0.04 & 5.43 & Trend increasing & S \\
\hline Rewari & 0.24 & 0.06 & 4.55 & Trend increasing & NS \\
\hline Sonipat & 0.26 & 0.04 & 5.43 & Trend increasing & S \\
\hline Yamunanagar & 0.11 & 0.40 & 1.84 & Trend increasing & NS \\
\hline
\end{tabular}


Fig.1 Crop coefficient values of wheat and rice

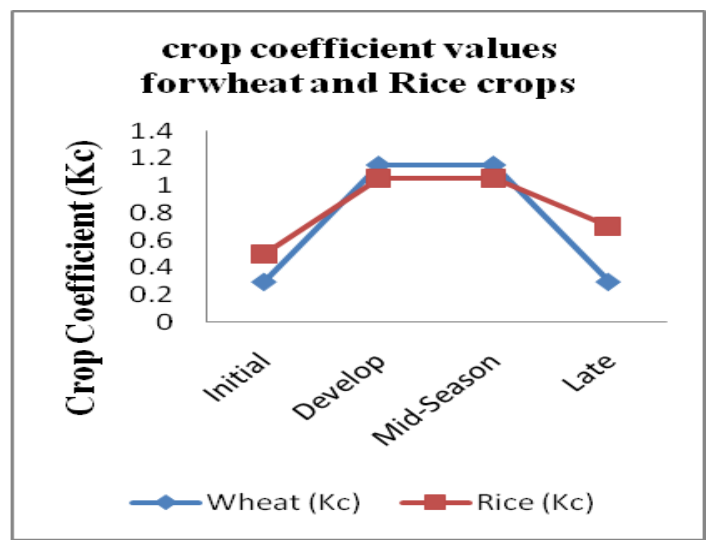

Fig.2 Spatial variation of crop water requirement of wheat
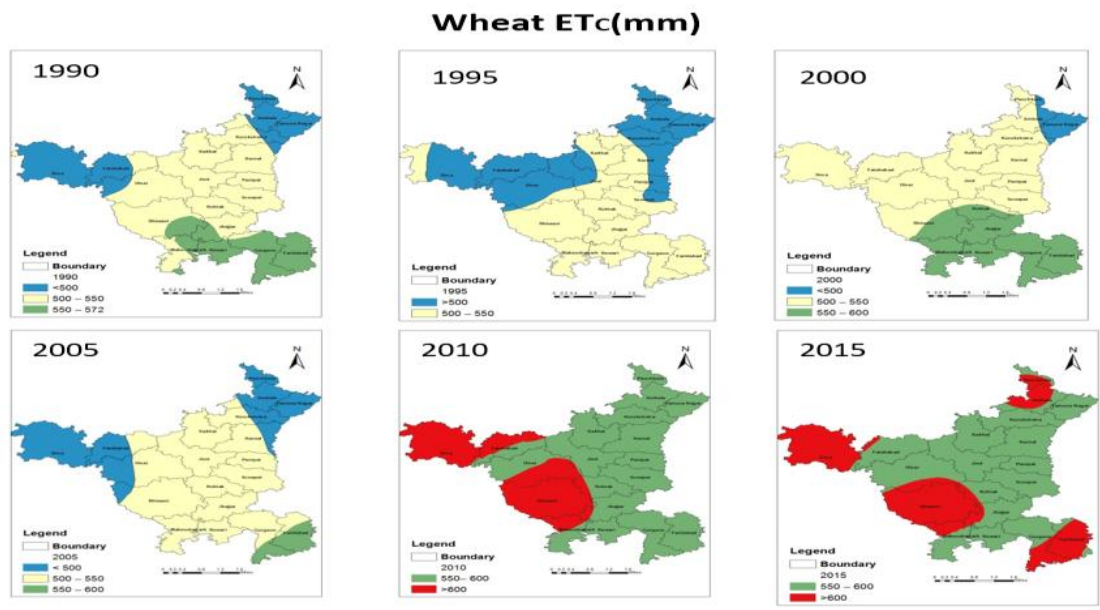

Fig.3 Spatial variation of crop water requirement of rice
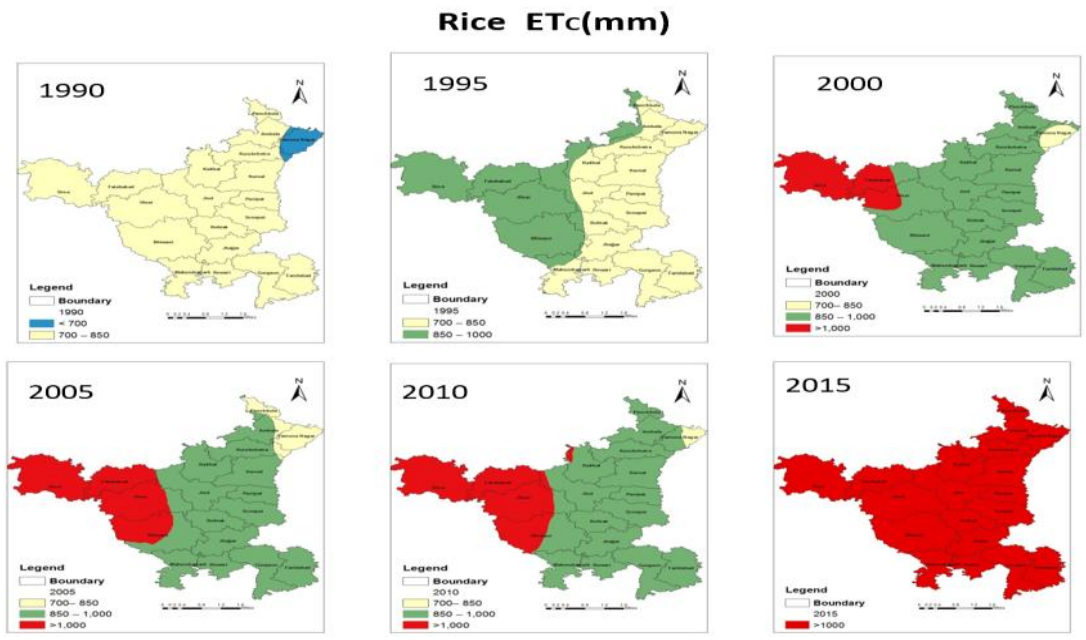
In the year 2010 only Bhiwani was the only district which was found more than $600 \mathrm{~mm}$ and the other remaining districts were found between the range 550-600 $\mathrm{mm}$. Among all eleven districts crop water requirement for Panchkula, Ambala, Bhiwani and Faridabad were observed more than $600 \mathrm{~mm}$ and the remaining districts were found between the range 550-600 $\mathrm{mm}$ during 2015 as shown in Fig.2.

Crop water requirement $\left(\mathrm{ET}_{\mathrm{C}}\right)$ of rice was increasing significantly only for eight districts viz. Bhiwani (Sen's slope 7.6), Fatehabad (Sen's slope 7.05), Hisar (Sen's slope 7.04), Sirsa (Sen's slope 10.9), Jind (Sen's slope 5.4), Kurukshetra (Sen's slope 4.6), Panipat (Sen's slope 5.4) and Sonipat (Sen's slope 5.4) but for other remaining districts no significant trend was observed (Table.2). The crop water requirement for all eight districts was found between the ranges $700-850 \mathrm{~mm}$ during the year 1990. Among all eight districts crop water requirement for Sirsa and Fatehabad was observed more than $1000 \mathrm{~mm}$ and the remaining six districts were found between the ranges $850-1000 \mathrm{~mm}$ in the year 2000. During the year $2010 \mathrm{ET}_{\mathrm{C}}$ was found more than $1000 \mathrm{~mm}$ for Sirsa, Fatehabad, Hisar and Bhiwani districts but in the year 2015 more than $1000 \mathrm{~mm}$ crop water demand was noticed for all districts (Fig.3)

The study shows that the crop water requirement for rice and wheat crops is increasing with the passage of time. The results obtained from the study can be used as a guide by farmers for selecting the amount and frequency of irrigation water for wheat and rice crops. Irrigation requirement will vary based on the availability of rainfall. Therefore, it is further suggested that water saving practices or techniques for water conservation should be adopted for irrigation on rice and wheat crops.

\section{Acknowledgement}

Authors are thankful to NASA Climatology Resources for Agroclimatology their services of free climatic data availability.

\section{References}

Ajay Singh, Peter Krause, Sudhindra N. Panda and Wolfgang-Albert Flugel. 2010. Rising water table: A threat to sustainable agriculture in an irrigated semi-arid region of Haryana, India. Agric. Water Manage., 97, pp.14431451.

Allen R G, Pereira L S, Raes D, Smith M. 1998. Crop Evapotranspiration: Guidelines for Computing Crop Water Requirements, FAO Irrigation and Drainage Paper 56. U.N. Food and Agriculture Organization (FAO), Rome. pp. 7-9.

Arunkumar Yadav, Hafeezunnisa, Pramod Kumar Kappadi. 2019. Crop Pattern Change and Crop Water Requirement Judgment using Remote Sensing and GIS Techniques: a research on Tungabhadra Dam Right Canal. International Journal of Recent Technology and Engineering (IJRTE) ISSN: 2277-3878, Volume-8, Issue2S3.

Cai J B, Liu Y, Lei T W, Pereira L S. 2007. Estimating reference evapotranspiration with the FAO Penman-Monteith equation using daily weather forecast messages. Agricultural and Forest Meteorology, 145, 22-35.

Gaurav Pakhale, Prasun Gupta, Jyoti Nale. 2010. Crop And Irrigation Water Requirement Estimation By Remote Sensing And GIS: A Case Study Of Karnal District, Haryana, India. International Journal of Engineering and Technology Vol.2(4),207-211.

Ketema Tezera, Gobena Dirirsa, Tilahun 
Hordofa. 2019. Determination of Wheat (Triticum aestivum L) Seasonal Water Demand and Crop Coefficient for Effective Irrigation Water Planning and Management in Semi-Arid, Central Rift Valley of Ethiopia. Int $\mathbf{J}$ Environ Sci Nat Res; 21(1): 556054. DOI: 10.19080/IJESNR.2019.21.556054.

Kuo S F, Chen F W, Liao P Y, Liu C W. (2011). A comparative study on the estimation of evapotranspiration using backpropagation neural network: Penman-Monteith method versus pan evaporation method. Paddy and Water Environment, 9, 413-424.

Lovelli S, Perniola M, Arcieri M, Rivelli A R, Tommason T D. (2008). Water use assessment in muskmelon by the Penman-Monteith "one-step" approach. Agricultural Water Management, 95, 1153-1160.

Vibhute, S. D., A. Sarangi and D.K. Singh. 2016. Development of Crop Water Demand Based Water Delivery Schedule for a Canal Command. Journal of Agricultural Engineering Vol. 53 (2). pp. 12-23.

Khandelwal, S. S. and Dr. S. D. Dhiman.
2017. Estimation of Net Irrigation Requirements of Crops in the Deterministic and Stochastic Regimes for Limbasi Canal Command Area, ICRISET International Conference on Re- search and Innovations in Science, Engineering \& Technology. Kalpa Publications in Civil Engineering, vol. 1, pp. 265-272.

S.K.Singh, Sujay Dutta and Nishith Dharaiya. 2013. Estimation of Crop Evapotranspiration of Cotton using Remote Sensing Technique. International Journal of Environmental Engineering and Management. ISSN 2231-1319, Volume 4(5), pp. 523-528.

Supit I, van Diepen C A, Boogaard H L, Ludwig F, Baruth B. 2010. Trend analysis of the water requirements, consumption and deficit of field crops in Europe. Agricultural and Forest Meteorology, 150, 77-88.

Yin Y H, Wu S H, Zheng D, Yang Q Y. 2008. Radiation calibration of FAO56 Penman-Monteith model to estimate reference crop evapotranspiration in China. Agricultural Water Management, 95, 77-84.

\section{How to cite this article:}

Shaloo, Himani Bisht, A. Sarangi, V. K. Prajapati, A. K. Mishra and Man Singh. 2021. Water Requirement and its Trend for Rice and Wheat Crops in Haryana State, India. Int.J.Curr.Microbiol.App.Sci. 10(02): 203-209. doi: https://doi.org/10.20546/ijcmas.2021.1002.025 